\title{
Use of Natural Raw Material Mixture and Natural Raw Potassium as Substitute for Chemical Fertilizers in Feeding Washington Navel Orange Trees under Kafr EI Sheikh Conditions. Somaia A. El-Sayed ${ }^{1}$ and A. R. El-Shereif ${ }^{2}$ ${ }^{1}$ Citrus Research Department, Hort. Res. Instit. ARC. Giza, Egypt. \\ ${ }^{2}$ Pomology Department, Faculty of Agriculture, Kafr El Sheikh University
}

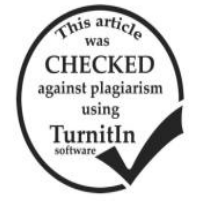

\section{ABSTRACT}

This study was done in a private orchard at Kafr El-Sheikh governorate, Egypt, during 2012 and 2013 seasons on 18 years old Washington navel orange trees on sour orange rootstock, to study the effect of fertilization with natural raw material mixture and natural raw material of potassium (feldspar) on growth, leaf NPK contents and productivity of trees. Results show that, natural raw material mixture and natural raw material of potassium (feldspar) applications significantly increased growth and leaf NPK contents as compared to regular mineral fertilizers. Moreover, natural raw material mixture and natural raw material of potassium (feldspar) treatments increased yield and improved fruit quality in terms of fruit weight, fruit size, juice size, TSS, acidity, TSS/acid ratio and vitamin C. The application of $4 \mathrm{~kg}$ natural raw material mixture/tree $+3 \mathrm{~kg} /$ tree natural raw material of potassium (feldspar) $+50 \mathrm{~kg}(\mathrm{MOM})$ is considered favorable treatment, which gave the best leaf NPK contents , growth, high yield and improving fruit quality of Washington navel orange trees. This treatment is a good substitute for using chemical fertilizers to avoid their deleterious effects on soil, water and human health.

Keywords: Feldspar, Citrus sinensis, Natural, Raw, Potassium, Rocks, orange.

\section{INTRODUCTION}

Washington navel orange (Citrus sinensis, L.) is considered as one of the most popular cultivar among citrus fruits in Egypt, for being of an excellent flavor, and high nutritional value because of their content from sugars, vitamins and minerals. Citrus fertilization is one of the most important factors for growth, reproductive behavior and ensure economic yield with a good quality. Chemical fertilizers are an indispensible in citrus crop nutrition, but it have some negative points such as: 1) represents more than $40 \%$ of citrus production costs, 2) excessive and indiscriminate uses have deleterious effects on soil, water and atmosphere pollution, and reflected on animal and human health, and 3) it adversely affected the soil fertility, water quality, yield and quality of the products (Srivastava, 2012 and Ennab, 2016). In order to improve productivity and access to safe fruits for local consumer and high exportation potential as well as reduce the costs, the farmers should be tend to the use natural raw material mixture and natural raw potassium (feldspar) as a natural sources for Fertilization. Using natural raw material and feldspar have numerous benefits that, its considered slow release fertilizer for macro elements, which make converting them in soluble forms of $\mathrm{P}, \mathrm{K}, \mathrm{Ca}$ and $\mathrm{Mg}$ in a long run (Hegazi et al., 2014), it has assumed great importance for sustainable production and to improve the soil physical, chemical and biological properties (Zayan et al., 2016). Also natural raw material mixture and natural raw potassium (feldspar) are a good alternative to reduce uses of chemical fertilizers (Abdel Rahman et al., 2009 and Eman et al., 2010). In this respect, several studies were accomplished for producing organic fruits through avoiding partially the application of chemicals fertilizers and encouraging the application of organic and natural raw material (rocks) fertilizers ( El-Boray et al.,2007, AbdelHak et al., 2012, Shaheen et al., 2013, El-Iraqy 2014, ElBoray et al .,2015 and Mostafa and Abdel Rahman 2015).

Therefore, the objective of this study is to evaluate and compare the effect of using natural raw material mixture and natural raw material of potassium (feldspar) as safe substitute for chemical fertilizers on growth, leaf mineral content, yield and fruit quality and fruit shelf life as well as fruit quality during shelf life period of Washington navel orange trees under Kafr El Sheikh conditions.

\section{MATERIALS AND METHODS}

The present study was carried out during 2012 and 2013 seasons in a private orchard at Kafr El-Sheikh governorate, Egypt, on eighteen years old Washington navel orange trees (Citrus sinensis, L.) budded on sour orange (Citrus aurantium L.) rootstock, planted at 5x5 meter apart in clay soil under flood irrigation system. The physical and chemical analysis of the experimental soil were determined according to the method described by Page et al. (1982) and shown in Table (1). Also, the used natural raw material mixture and natural raw material of potassium (feldspar) were analyzed as shown in Table (1). Twenty four trees uniform in growth, vigour and productivity were selected, and subjected to the same cultural practices commonly adopted on the orchard, except fertilization. Trees were arranged in a randomized complete block design, each treatment replicated three time with two tree per replicate. The chosen

- $\mathrm{T}_{1}: 50 \mathrm{~kg}(\mathrm{MOM})+2 \mathrm{~kg}$ Natural Raw Material Mixture $/$ tree $+3 \mathrm{~kg} /$ tree feldspar

- $\mathrm{T}_{2}: 50 \mathrm{~kg}(\mathrm{MOM})+4 \mathrm{~kg}$ Natural Raw Material Mixture/tree $+3 \mathrm{~kg} /$ tree feldspar

- $\mathrm{T}_{3}: 50 \mathrm{~kg}(\mathrm{MOM})+6 \mathrm{~kg}$ Natural Raw Material Mixture/tree $+3 \mathrm{~kg} /$ tree feldspar

- Control: Farmer program fertilization was considered as Control

The program fertilization was 1000:250:500 NPK $\mathrm{g} /$ tree/year applied as $4.85 \mathrm{~kg} /$ tree ammonium sulphate $(20.6 \% \mathrm{~N}), 1.60 \mathrm{~kg} /$ tree super phosphate $(15.5 \% \mathrm{P} 2 \mathrm{O} 5)$ and $1.00 \mathrm{~kg} /$ tree potassium sulphate $(48 \% \mathrm{~K} 2 \mathrm{O})$. Nitrogen fertilizer was added on three doses, at March, the first of June and at the end of August. Whereas, potassium was applied on two doses, at the first of March and at the end of August with nitrogen fertilization. All fertilizers added as broadcast on the soil surface through the whole area. Natural raw material mixture and natural raw material of potassium (feldspar) were added once at the first week of 
December in both seasons. Therefore, mature organic manure was applied at winter service at the first week of December in both seasons, at the same time of applying
Natural mixture and Feldspar. Mature organic manure (MOM) was added as $50 \mathrm{~kg} /$ tree, to all experimental trees except control trees.

Table 1. Analysis of natural raw material mixture, natural raw potassium (feldspar) and physical, chemical of the experimental soil.

\begin{tabular}{|c|c|c|c|c|c|c|c|c|}
\hline \multirow{3}{*}{ Soil properties } & \multicolumn{4}{|c|}{ Soil depth cm } & \multirow{2}{*}{\multicolumn{2}{|c|}{$\begin{array}{l}\text { Natural raw material } \\
\text { mixture }\end{array}$}} & \multirow{2}{*}{\multicolumn{2}{|c|}{$\begin{array}{l}\text { Natural raw of } \\
\text { potassium (feldspar }\end{array}$}} \\
\hline & \multicolumn{4}{|c|}{$\begin{array}{c}\text { Before experiment After } \\
\text { experiment } \\
(2013) \quad(2015)\end{array}$} & & & & \\
\hline & $\mathbf{0}-\mathbf{3 0}$ & $30-60$ & $\mathbf{0}-\mathbf{3 0}$ & $30-60$ & Component & concentration & Component & Concentration \\
\hline $\mathrm{pH}(1: 2.5$ soil suspension) & 8.06 & 8.183 & 8.02 & 8.13 & $\mathrm{SiO}_{2}$ & $36.15 \%$ & $\mathrm{SiO}_{2}$ & 70.56 \\
\hline \multirow{6}{*}{$\begin{array}{l}\mathrm{EC}, \mathrm{dS} / \mathrm{m}(1: 5 \text { soil water } \\
\text { extract }) \\
\text { Soluble cations and anions } \\
\text { meq/L }\end{array}$} & 3.60 & 2.40 & 3.55 & 2.23 & $\mathrm{TiO}_{2}$ & $0.76 \%$ & $\mathrm{TiO}_{2}$ & 0.02 \\
\hline & & & & & $\mathrm{Al}_{2} \mathrm{O}_{3}$ & $7.80 \%$ & $\mathrm{AL}_{2} \mathrm{O}_{3}$ & 16.23 \\
\hline & & & & & $\mathrm{Fe}_{2} \mathrm{O}_{3}$ & $4.88 \%$ & $\mathrm{Fe}_{2} \mathrm{O}_{3}$ & 0.17 \\
\hline & & & & & $\mathrm{MnO}$ & $0.72 \%$ & $\mathrm{MnO}$ & 0.02 \\
\hline & & & & & $\mathrm{MgO}$ & $3.07 \%$ & $\mathrm{MgO}$ & 0.05 \\
\hline & & & & & $\mathrm{CaO}$ & $13.45 \%$ & $\mathrm{CaO}$ & 0.26 \\
\hline $\mathrm{Na}^{+}$ & 0.84 & 1.28 & 0.80 & 1.24 & $\mathrm{Na}_{2} \mathrm{O}$ & $1.92 \%$ & $\mathrm{Na}_{2} \mathrm{O}$ & 3.69 \\
\hline $\mathrm{K}^{+}$ & 0.91 & 0.45 & 0.96 & 0.48 & $\mathrm{~K}_{2} \mathrm{O}$ & $4.37 \%$ & $\mathrm{~K}_{2} \mathrm{O}$ & 8.20 \\
\hline $\mathrm{Ca}^{++}$ & 2.70 & 1.60 & 2.73 & 1.65 & $\mathrm{P}_{2} \mathrm{O}_{5}$ & $8.14 \%$ & $\mathrm{P}_{2} \mathrm{O}_{5}$ & 0.03 \\
\hline $\mathrm{Mg}^{++}$ & 2.80 & 1.60 & 2.84 & 1.64 & $\mathrm{Cl}$ & $0.56 \%$ & L.O.I & 0.37 \\
\hline $\mathrm{Cl}^{-}$ & 0.80 & 0.60 & 0.80 & 1.60 & $\mathrm{SO}_{3}$ & $5.38 \%$ & & \\
\hline $\mathrm{CO}_{3}{ }^{-}$ & 0.00 & 0.00 & 0.00 & 0.00 & L.O.I & $9.01 \%$ & & \\
\hline $\mathrm{SO}_{4-}^{-}$ & 1.40 & 1.30 & 1.40 & 1.30 & V & $248.1 \mathrm{ppm}$ & & \\
\hline \multirow[t]{2}{*}{$\mathrm{HCO}_{3}$} & 5.05 & 3.03 & 5.00 & 3.00 & $\mathrm{Cr}$ & $339.4 \mathrm{ppm}$ & & \\
\hline & & & & & $\mathrm{Co}$ & $17.5 \mathrm{ppm}$ & & \\
\hline Total N, \% & 0.15 & 0.11 & 0.18 & 0.13 & $\mathrm{Ni}$ & $25.8 \mathrm{ppm}$ & & \\
\hline Available $\mathrm{P}, \mathrm{mg} / \mathrm{kg}$ soil & 15.2 & 7.90 & 15.4 & 7.96 & $\mathrm{Cu}$ & $17.8 \mathrm{ppm}$ & & \\
\hline Available K, mg/kg soil & 1154 & 800 & 1155 & 803 & $\mathrm{Zn}$ & $3082.0 \mathrm{ppm}$ & & \\
\hline Organic matter, $\%$ & 1.31 & 0.99 & 1.35 & 1.20 & $\mathrm{Rb}$ & $46.0 \mathrm{ppm}$ & & \\
\hline Field Capacity, $\%$ & 45.2 & 46.1 & 45.3 & 46.5 & $\mathrm{Sr}$ & $246.2 \mathrm{ppm}$ & & \\
\hline Wilting point, $\%$ & 23.8 & 24.5 & 23.9 & 23.5 & $\mathrm{Y}$ & $<1.5 \mathrm{ppm}$ & & \\
\hline Available water, $\%$ & 21.4 & 21.6 & 21.4 & 21.6 & $\mathrm{Zr}$ & $54.5 \mathrm{ppm}$ & & \\
\hline Bulk density, $\mathrm{Mg} / \mathrm{m}^{3}$ & 1.27 & 1.44 & 1.29 & 1.46 & $\mathrm{Nb}$ & $5.7 \mathrm{ppm}$ & & \\
\hline \multirow[t]{3}{*}{ Particle size distribution , $\%$} & & & & & Mo & $2.4 \mathrm{ppm}$ & & \\
\hline & & & & & $\mathrm{Sn}$ & $2.5 \mathrm{ppm}$ & & \\
\hline & & & & & $\mathrm{Ba}$ & $545.0 \mathrm{ppm}$ & & \\
\hline Clay & 66.5 & 67.4 & 66.5 & 67.4 & $\mathrm{La}$ & $14.7 \mathrm{ppm}$ & & \\
\hline Silt & 27.9 & 27.2 & 27.9 & 27.2 & $\mathrm{Yb}$ & $3.9 \mathrm{ppm}$ & & \\
\hline sand & 5.6 & 5.4 & 5.6 & 5.4 & Hf & $2.7 \mathrm{ppm}$ & & \\
\hline \multirow{2}{*}{ Texture class } & & & & & $\mathrm{Ta}$ & $4.4 \mathrm{ppm}$ & & \\
\hline & Clay & Clay & Clay & Clay & $\mathrm{Pb}$ & $1104.0 \mathrm{ppm}$ & & \\
\hline
\end{tabular}

The following data was recorded:

Twenty mature leaves were sampled in September from spring shoot to determining leaf area $\left(\mathrm{cm}^{2}\right)$ using a leaf area meter Model Li 3100 areameter, then leaf samples were washed with tap water followed by distilled water and dried at $70^{\circ} \mathrm{C}$ to a constant weight, then the dry leaves were ground and digested according to Chapman and Pratt (1961) and Jackson (1967) by using the mixture of concentrated Sulfuric acid $\left(\mathrm{H}_{2} \mathrm{SO}_{4}\right)+$ perchloric $\left(\mathrm{HClO}_{4}\right)(5: 1)$ to determine the elements $\mathrm{N}, \mathrm{P}$ and $\mathrm{K}$. Total nitrogen \% was determined by using the micro-kjeldahl method as described by Pregl (1945), Phosphorus \% was determined coloremetrically as described by Murphy and Riley (1962) while, Potassium \% was estimated by using flame photometer as described by Brown and Lillelland (1974). At harvest time (15 December in both seasons), yield of each tree was determined as number and weight $(\mathrm{kg})$ of fruits/tree, then 10 fruit samples were taken at random from each replicate and directly transported to laboratory of Horticulture Department, Faculty of Agriculture, Kafr El Sheikh University to determine fruit quality as follow: fruit weight (gm), fruit size (ml), juice size $\mathrm{ml} /$ fruit, were measured. Total soluble solids (TSS\%) was determined by hand refractometer, total acidity as citric acid according to
(AO A C 1990), ascorbic acid as $\mathrm{mg} / 100 \mathrm{ml}$ juice by using 2, 6 dichlorophenol indophenol according to Jacobs (1951). TSS/acid ratio was estimated. The remaining fruit samples (25 fruits) were left in the laboratory at room temperature $\left(21 \pm 1^{\circ} \mathrm{C}\right)$ and humidity $(60 \pm 5 \%$ ) for a period of five weeks to estimate fruit quality and weight loss during shelf life period. The variables were measured every week as follow: Fruit weight loss (\%) according to this equation:

Weight loss $\%=\frac{\text { Initial weight }- \text { weight at each week } \times 100}{\text { Initial weight }}$.

Total soluble solid (TSS \%), acidity \%, vitamin $\mathrm{C}$ and TSS/acid ratio according to (AOAC 1990).

Statistical analysis was done as analysis of variance according to the method described by Snedecor and Cochran (1990), and the least significant differences (LSD. at 5\% level) was used to compare mean values.

\section{RESULTS AND DISCUSSION}

\section{Leaf area $\left(\mathrm{cm}^{2}\right)$ :}

Data reported in Tables 2 and 3 show the effect of natural raw material mixture and natural raw potassium (feldspar) on leaf area and leaf NPK content of Washington navel orange trees. As for leaf area the results in Table 2 indicated that, all treatments increased leaf area 
as compared to control treatment. The application of $4 \mathrm{~kg}$ natural raw material mixture/tree $+3 \mathrm{~kg} /$ tree feldspar +50 $\mathrm{kg}$ M.O.M (T2) was significantly increased leaf area compared to the control treatment. T1 (2 kg Natural Raw Material Mixture $/$ tree $+3 \mathrm{~kg} /$ tree feldspar $+50 \mathrm{~kg}$ M.O.M ) and T3 (6 kg Natural Raw Material Mixture/tree +3 $\mathrm{kg} /$ tree feldspar+50 $\mathrm{kg}$ M.O.M) gave approximately the same values of leaf area without significant differences between them. Moreover, the increment over control represented $9.55,14.40$ and $6.81 \%$ for $\mathrm{T} 1, \mathrm{~T} 2$ and $\mathrm{T} 3$, respectively. These findings are in agreement with those obtained by Barakat et al. (2012) on Newhall navel orange and Abdel-Hak et al. (2012) on Valencia orange trees. In this respect, Eman et al. (2010) using natural raw material mixture and magnetite raw on Le Conte pear trees and found an increasing in vegetative growth in terms of shoot length, shoot diameter, leaf number and leaf area as compared to NPK treated ones. Also, Abdel Rahman et al. (2009) revealed that, application of $5 \mathrm{~kg}$ natural elements compound per tree significantly improved vegetative growth of navel orange compared to control.

\section{Leaf NPK content:}

As for leaf $\mathrm{N}$ content, data presented in Table 2 indicate that, all treatments of natural raw material mixture and natural raw potassium (feldspar) were raising leaf nitrogen content compared to control treatment, whereas there are insignificant differences among treatments on this variable. Moreover, leaf $\mathrm{N}$ content was increased over control caused by treatments, this increment was higher in $\mathrm{T}_{2}(4 \mathrm{~kg}$ natural raw material mixture/tree $+3 \mathrm{~kg} /$ tree feldspar $+50 \mathrm{~kg}$ M.O.M) followed by $\mathrm{T}_{1}$ ( $2 \mathrm{~kg}$ Natural Raw Material Mixture $/$ tree $+3 \mathrm{~kg} /$ tree feldspar $+50 \mathrm{~kg}$ M.O.M) and $\mathrm{T}_{3}$ (6 kg Natural Raw Material Mixture/tree $+3 \mathrm{~kg} /$ tree feldspar $+50 \mathrm{~kg}$ M.O.M) respectively. These results are similar with those reported by Mohamed (2008) on Superior grapevines grown in a sandy soil and irrigated with drip irrigation system; found that the leaf nitrogen content was higher in vines fertilized with $8 \mathrm{~kg}$ compost $+400 \mathrm{~g}$ rock phosphate $+400 \mathrm{~g}$ feldspar than that on control vines fertilized with chemical sources. Similar results were obtained by Shaheen et al. (2013), they indicated that application of $50 \%$ compost $+50 \%$ P rock phosphate $+50 \% \mathrm{~K}$ feldspar $+50 \%$ of the NPK mineral recommended fertilizers + bio-fertilizer (Azotobacter chrococcum, Bacillus megaterium and Bacillus circulans) gave the best leaf nitrogen content of Superior Seedless grapevines.

Table 2. Effect of natural raw material mixture and feldspar on leaf area and leaf nitrogen content of Washington navel orange trees.

\begin{tabular}{|c|c|c|c|c|c|c|c|c|}
\hline \multirow[b]{2}{*}{ Treatments } & \multicolumn{4}{|c|}{ Leaf area $\left(\mathrm{cm}^{2}\right)$} & \multicolumn{4}{|c|}{ Leaf nitrogen (\%) } \\
\hline & $\begin{array}{c}2012 \\
\text { season }\end{array}$ & $\begin{array}{c}2013 \\
\text { Season }\end{array}$ & Average & $\begin{array}{c}\text { \%Increasing or } \\
\text { Decreasing than } \\
\text { control }\end{array}$ & $\begin{array}{c}2012 \\
\text { Season }\end{array}$ & $\begin{array}{c}2013 \\
\text { Season }\end{array}$ & Average & $\begin{array}{l}\text { \%Increasing or } \\
\text { decreasing than } \\
\text { control }\end{array}$ \\
\hline Control & $13.90 \mathrm{c}$ & $14.58 \mathrm{~b}$ & 14.24 & 0.00 & $2.27 \mathrm{a}$ & $2.21 \mathrm{a}$ & 2.24 & 0.00 \\
\hline $\mathrm{T}_{1}$ & $15.40 \mathrm{~b}$ & $15.80 \mathrm{ab}$ & 15.60 & +9.55 & $2.85 \mathrm{a}$ & $2.09 \mathrm{a}$ & 2.47 & +10.26 \\
\hline $\mathrm{T}_{2}$ & $16.26 \mathrm{a}$ & $16.32 \mathrm{a}$ & 16.29 & +14.40 & $2.50 \mathrm{a}$ & $2.50 \mathrm{a}$ & 2.50 & +11.60 \\
\hline $\mathrm{T}_{3}$ & $15.17 \mathrm{~b}$ & $15.24 \mathrm{ab}$ & 15.21 & +6.81 & $2.37 \mathrm{a}$ & $2.37 \mathrm{a}$ & 2.37 & +5.80 \\
\hline LSD at $5 \%$ & 0.551 & 1.32 & -- & -- & Ns & Ns & -- & -- \\
\hline
\end{tabular}

- T $_{1} 50 \mathrm{~kg}$ M O M + 2 kg Natural Raw Material Mixture/tree + 3 kg/tree feldspar

- $T_{2} 50 \mathrm{~kg} \mathrm{MOM}+4 \mathrm{~kg}$ Natural Raw Material Mixture/tree $+3 \mathrm{~kg} /$ tree feldspar

- $T_{3} 50 \mathrm{~kg}$ M O M + $6 \mathrm{~kg}$ Natural Raw Material Mixture /tree + $3 \mathrm{~kg} /$ tree feldspar

- Control Farmer program fertilization

NS = not significant

Leaf $\mathrm{P}$ content in Washington navel orange trees recorded the highest value in $\mathrm{T}_{3}$ followed by control treatment in both seasons (Table 3). The lowest values were noticed with $T_{1}$ in both seasons. The statistical analysis showed that differences were insignificant among treatments in both seasons. Also, data in Table (3) showed that leaf content of phosphorus was decreased by $10 \%$ and $5 \%$ of control in $\mathrm{T}_{1}$ and $\mathrm{T}_{2}$ respectively, whereas $\mathrm{T}_{3}$ was increased leaf content of phosphorus by $5 \%$ of control. Similar results were obtained by Mostafa and Abdel Rahman (2015) on Balady mandarin.

Table 3. Effect of natural raw material mixture and feldspar on leaf phosphorus and Potassium content of Washington navel orange trees.

\begin{tabular}{|c|c|c|c|c|c|c|c|c|}
\hline \multirow[b]{2}{*}{ Treatments } & \multicolumn{4}{|c|}{ Leaf phosphorus (\%) } & \multicolumn{4}{|c|}{ Leaf potassium( $\%)$} \\
\hline & $\begin{array}{c}2012 \\
\text { Season }\end{array}$ & $\begin{array}{c}2013 \\
\text { Season }\end{array}$ & Average & $\begin{array}{l}\text { \% Increasing } \\
\text { or decreasing } \\
\text { than control }\end{array}$ & $\begin{array}{c}2012 \\
\text { Season }\end{array}$ & $\begin{array}{c}2013 \\
\text { Season }\end{array}$ & Average & $\begin{array}{c}\text { \% Increasing or } \\
\text { decreasing than } \\
\text { control }\end{array}$ \\
\hline Control & $0.21 \mathrm{a}$ & $0.20 \mathrm{a}$ & 0.20 & 0.00 & $2.29 \mathrm{a}$ & $2.66 \mathrm{a}$ & 2.48 & 0.00 \\
\hline $\mathrm{T}_{1}$ & $0.18 \mathrm{a}$ & $0.17 \mathrm{a}$ & 0.18 & -10.00 & $2.10 \mathrm{~b}$ & $2.44 \mathrm{a}$ & 2.27 & -8.47 \\
\hline $\mathrm{T}_{2}$ & $0.19 \mathrm{a}$ & $0.18 \mathrm{a}$ & 0.19 & -5.00 & $2.21 \mathrm{ab}$ & $2.33 \mathrm{a}$ & 2.27 & -8.47 \\
\hline $\mathrm{T}_{3}$ & $0.22 \mathrm{a}$ & $0.20 \mathrm{a}$ & 0.21 & +5.00 & $2.28 \mathrm{a}$ & $2.61 \mathrm{a}$ & 2.45 & -1.21 \\
\hline LSD at $5 \%$ & NS & NS & -- & -- & 0.16 & NS & -- & -- \\
\hline
\end{tabular}

- $T_{1} 50 \mathrm{~kg}$ M O M + 2 kg Natural Raw Material Mixture/tree + 3 kg/tree feldspar

- $T_{2} 50 \mathrm{~kg}$ M O M + $4 \mathrm{~kg}$ Natural Raw Material Mixture/tree + $3 \mathrm{~kg} /$ tree feldspar

- $\mathrm{T}_{3} 50 \mathrm{~kg}$ M O M + $6 \mathrm{~kg}$ Natural Raw Material Mixture /tree + $3 \mathrm{~kg} /$ tree feldspar

- Control Farmer program fertilization

NS = not significant

Regarding leaf $\mathrm{K}$ content, data in Table 3 revealed that control treatment and $\mathrm{T}_{3}$ gave higher values of leaf potassium content compared to other treatments in both seasons. The differences were significant in the first season only. All treatments reduced of leaf potassium content at different rates of 
control. This values were found in treatments of $\mathrm{T} 3, \mathrm{~T}_{1}$ and $\mathrm{T}_{2}$ with $-1.21,-8.47$ and $-8.47 \%$, respectively.

Generally, it is obvious from data in Tables (2 and 3) that, application of natural raw material mixture and natural raw potassium (feldspar) enhanced vegetative growth of Washington navel orange trees. $T_{2}$ (4 kg natural raw material mixture/tree $+3 \mathrm{~kg}$ /tree feldspar $+50 \mathrm{~kg}$ M.O.M) was more effective as compared to other treatments. In this respect, the results in Tables ( 2 and 3 ) revealed that leaf NPK contents was optimal for Washington navel orange growth and productivity under all treatments, these results came true with Embleton et al. (1978) and Koo et al. (1984). The reduction in leaf $P$ and $K$ content as result of $T_{1}, T_{2}$ and $\mathrm{T}_{3}$ treatments than control can be attributed to natural raw material and feldspar are considered slow release fertilizer for macro elements which take a long time for converting them in soluble forms (Roy et al. 2006). It is worthily to mention that applying these raw materials mixture and feldspar to the experimental soil has been led to improve most of soil properties, in terms of PH., $\mathrm{EC}$, soluble actions and anions values and available $\mathrm{P}$ and $\mathrm{K}$ as $\mathrm{mg} / \mathrm{kg}$ soil after the end of this experiment in 2015 as shown in Table 1. In spite of the improving is seemed to be slightly occurred after two years of application, probably, it will be promising in the long term application instead of chemical fertilizers.

Yield as kg/tree and fruit number/tree:

Data in Table 4 showed that, yield as number of fruits and weight $(\mathrm{kg} /$ tree) of Washington navel orange trees was significantly increased by all natural raw material mixture and natural raw potassium (feldspar) treatments comparing with control in both seasons. In this respect, the highest yield was observed with fertilization application of $\mathrm{T}_{3}$ and $\mathrm{T}_{2}$ in both seasons, respectively. However, trees fertilized with farmer program (control) gave the lowest yield compared to other treatments in both seasons. In addition, $\mathrm{T}_{3}, \mathrm{~T}_{2}$ and $\mathrm{T}_{1}$ gave highest yield over control, $30.65,19.47$ and $16.47 \%$ for yield as $\mathrm{kg} /$ tree and 15.90 , 12.26 and $11.47 \%$ for number of fruits/tree, respectively. These results were in agreement with those obtained by Abdel-Hak et al. (2012), they reported that, feldspar at $1000 \mathrm{~g} \mathrm{~K}_{2} \mathrm{O}$ /tree with two or three doses inoculated with Bacillus circulans as soil application on Valencia orange gave the highest significant fruit number and yield $\mathrm{kg} /$ tree as compared with control and other treatments. Similarly, El-Wakeel et al. (2013) observed that feldspar + silicate bacteria enhanced yield of Navel orange trees. In this respect, El-Iraqy (2014) found that olive trees cv. Picual fertilized with $3 \mathrm{~kg} /$ tree feldspar plus $134 \mathrm{~g}$ Potassium enhanced tree yield as $\mathrm{kg} /$ tree compared to the control and other treatments. The increment in yield by using natural raw material mixture and natural raw potassium (feldspar) may be due to their great abilities for providing with various nutrients for the trees needed to increase yield and improving physical and chemical of soil properties. This positive effect most probably due to that the treated trees are not suffering from deficiency of both macro and micro nutrient.

Table 4. Effect of natural raw material mixture and feldspar on yield of Washington navel orange trees.

\begin{tabular}{|c|c|c|c|c|c|c|c|c|}
\hline \multirow[b]{2}{*}{ Treatments } & \multicolumn{4}{|c|}{ Yield as kg/tree } & \multicolumn{4}{|c|}{ Yield as fruit number/tree } \\
\hline & $\begin{array}{c}2012 \\
\text { Season }\end{array}$ & $\begin{array}{c}2013 \\
\text { Season }\end{array}$ & Average & $\begin{array}{l}\text { \%Increasing } \\
\text { or decreasing } \\
\text { than control }\end{array}$ & $\begin{array}{c}2012 \\
\text { Season }\end{array}$ & $\begin{array}{c}2013 \\
\text { Season }\end{array}$ & Average & $\begin{array}{c}\text { \%Increasing or } \\
\text { decreasing } \\
\text { than control }\end{array}$ \\
\hline Control & $59.05 \mathrm{c}$ & $61.84 \mathrm{c}$ & 60.44 & 00.00 & $300.00 \mathrm{~b}$ & $310.00 \mathrm{~b}$ & 305.00 & 00.00 \\
\hline $\mathrm{T}_{1}$ & $70.18 \mathrm{~b}$ & $70.63 \mathrm{~b}$ & 70.40 & +16.47 & $343.70 \mathrm{ab}$ & $336.33 \mathrm{ab}$ & 340.01 & +11.47 \\
\hline $\mathrm{T}_{2}$ & $71.90 \mathrm{ab}$ & $72.52 \mathrm{ab}$ & 72.21 & +19.47 & $339.50 \mathrm{ab}$ & $345.30 \mathrm{a}$ & 342.41 & +12.26 \\
\hline $\mathrm{T}_{3}$ & $80.35 a$ & $77.60 \mathrm{a}$ & 78.97 & +30.65 & $372.17 \mathrm{a}$ & $334.83 \mathrm{ab}$ & 353.50 & +15.90 \\
\hline LSD at $5 \%$ & 9.98 & 3.37 & -- & -- & 70.33 & 29.04 & -- & -- \\
\hline
\end{tabular}

$\boldsymbol{T}_{1}$ 50kg M O M + $2 \mathrm{~kg}$ Natural Raw Material Mixture/tree + $3 \mathrm{~kg} /$ tree feldspar

- $T_{2} 50 \mathrm{~kg}$ M O M + $4 \mathrm{~kg}$ Natural Raw Material Mixture/tree $+3 \mathrm{~kg} /$ tree feldspar

- $T_{3} 50 \mathrm{~kg}$ M O M + $6 \mathrm{~kg}$ Natural Raw Material Mixture $/$ tree $+3 \mathrm{~kg} /$ tree feldspar

- Control: Farmer program fertilization

Fruit quality:

\section{Physical characters:}

Data in Table 5 show the effect of natural raw material mixture and natural raw potassium (feldspar) on physical fruit quality in terms of fruit weight, size and juice size of Washington navel orange trees in both seasons. The results show significant differences among treatments in both seasons as for fruit size and juice size, while the differences were not significant as for fruit weight in both seasons. All tested treatments increased fruit weight, fruit size and juice size compared to control in both seasons. The highest values of fruit weight, fruit size and juice size were obtained from trees fertilized with $\mathrm{T}_{3} \quad(6 \mathrm{~kg}$ Natural Raw Material Mixture/tree $+3 \mathrm{~kg} /$ tree feldspar $+50 \mathrm{~kg}$ MOM) followed by $\mathrm{T}_{2}$ (4 $\mathrm{kg}$ Natural Raw Material Mixture/tree $+3 \mathrm{~kg} /$ tree feldspar $+50 \mathrm{~kg} \mathrm{MOM})$ as compared with control trees and other treatments in both seasons. On the other hand, control treatment (Farmer program fertilization) gave the least values of fruit weight, fruit size and juice size in both seasons. Moreover, $\mathrm{T}_{3}$ and $\mathrm{T}_{2}$ gave higher increasing over control and other treatments. Similar results were obtained by Shaaban et al. (2012), and Mostafa and Abdel Rahman (2015). In this respect, Abdel Rahman et al. (2009) on Navel orange found that natural elements compound application improved fruit weight and juice volume. On the other hand, Eman et al (2010) found no differences between using natural raw material mixture and NPK treatments on physical fruit quality in terms of fruit weight, fruit length and diameter of Le Conte pear trees.

Generally, it is clear from Table 5 that, heaviest and largest fruits were harvested from trees treated with $6 \mathrm{~kg}$ Natural Raw Material Mixture/tree $+3 \mathrm{~kg} /$ tree feldspar $+50 \mathrm{~kg}$ MOM followed by those treated with 4 $\mathrm{kg}$ Natural Raw Material Mixture/tree $+3 \mathrm{~kg} /$ tree feldspar $+50 \mathrm{~kg}$ MOM without significant differences between them in both seasons. 
Table 5. Effect of natural raw material mixture and feldspar on fruit weight (g), fruit size (ml) and juice size (ml/fruit) of Washington navel orange trees.

\begin{tabular}{|c|c|c|c|c|c|c|c|c|}
\hline \multirow[b]{2}{*}{ Treatments } & \multicolumn{4}{|c|}{ Fruit weight (g) } & \multicolumn{4}{|c|}{ Fruit size (ml) } \\
\hline & $\begin{array}{c}2012 \\
\text { Season }\end{array}$ & $\begin{array}{c}2013 \\
\text { Season }\end{array}$ & Average & $\begin{array}{l}\text { \% Increasing } \\
\text { or decreasing } \\
\text { than control }\end{array}$ & $\begin{array}{c}2012 \\
\text { Season }\end{array}$ & $\begin{array}{c}2013 \\
\text { Season }\end{array}$ & Average & $\begin{array}{l}\text { \%Increasing } \\
\text { or decreasing } \\
\text { than control }\end{array}$ \\
\hline$\overline{\text { Control }}$ & $196.83 a$ & $199.40 \mathrm{a}$ & 198.11 & 00.00 & $174.17 b$ & $185.00 \mathrm{~d}$ & 179.58 & 00.00 \\
\hline $\mathrm{T}_{1}$ & $204.20 \mathrm{a}$ & $209.20 \mathrm{a}$ & 206.70 & +4.33 & $211.67 \mathrm{~b}$ & $199.00 \mathrm{c}$ & 205.33 & +14.34 \\
\hline $\mathrm{T}_{2}$ & $211.80 \mathrm{a}$ & $218.70 \mathrm{a}$ & 215.25 & +8.65 & $271.67 \mathrm{a}$ & $222.57 \mathrm{~b}$ & 247.12 & +37.61 \\
\hline $\mathrm{T}_{3}$ & $215.90 \mathrm{a}$ & $222.80 \mathrm{a}$ & 219.35 & +10.72 & $279.17 \mathrm{a}$ & $245.00 \mathrm{a}$ & 262.09 & +45.95 \\
\hline LSD at $5 \%$ & NS & NS & -- & -- & 73.23 & 9.88 & -- & -- \\
\hline & \multicolumn{8}{|c|}{ Juice volume (ml/fruit) } \\
\hline Treatments & \multicolumn{2}{|c|}{$\begin{array}{c}2012 \\
\text { Season }\end{array}$} & \multicolumn{2}{|c|}{$\begin{array}{c}2013 \\
\text { Season }\end{array}$} & \multicolumn{2}{|c|}{ Average } & \multicolumn{2}{|c|}{$\begin{array}{c}\% \text { Increasing than } \\
\text { control }\end{array}$} \\
\hline Control & \multicolumn{2}{|c|}{$62.00 \mathrm{~b}$} & \multicolumn{2}{|c|}{$58.00 \mathrm{c}$} & \multicolumn{2}{|c|}{60.00} & \multicolumn{2}{|c|}{00.00} \\
\hline $\mathrm{T}_{1}$ & \multicolumn{2}{|c|}{$63.33 \mathrm{~b}$} & \multicolumn{2}{|c|}{$62.00 \mathrm{c}$} & \multicolumn{2}{|c|}{62.66} & \multicolumn{2}{|c|}{+4.43} \\
\hline $\mathrm{T}_{2}$ & \multicolumn{2}{|c|}{$73.33 \mathrm{a}$} & \multicolumn{2}{|c|}{$67.50 \mathrm{~b}$} & \multicolumn{2}{|c|}{70.41} & \multicolumn{2}{|c|}{+17.35} \\
\hline $\mathrm{T}_{3}$ & \multicolumn{2}{|c|}{$80.33 \mathrm{a}$} & \multicolumn{2}{|c|}{$82.00 \mathrm{a}$} & \multicolumn{2}{|c|}{81.16} & \multicolumn{2}{|c|}{+35.26} \\
\hline LSD at $5 \%$ & \multicolumn{2}{|c|}{9.98} & \multicolumn{2}{|r|}{2.99} & \multicolumn{2}{|c|}{-- } & \multicolumn{2}{|r|}{-- } \\
\hline
\end{tabular}

- $\mathrm{T}_{1} 50 \mathrm{~kg}$ M O M + $2 \mathrm{~kg}$ Natural Raw Material Mixture/tree $+3 \mathrm{~kg} /$ tree feldspar

- $T_{2} 50 \mathrm{~kg}$ M O M + $4 \mathrm{~kg}$ Natural Raw Material Mixture/tree $+3 \mathrm{~kg} /$ tree feldspar

- $T_{3} 50 \mathrm{~kg}$ M O M + $6 \mathrm{~kg}$ Natural Raw Material Mixture /tree + $3 \mathrm{~kg} /$ tree feldspar

- Control: Farmer program fertilization

NS = not significant

Chemical characters:

Data in Tables 6 and 7 show the effect of soil application of natural raw material mixture and natural raw potassium (feldspar) on chemical fruit quality in terms of TSS $\%$, acidity $\%$, TSS/acid ratio and vitamin C of Washington navel orange trees in both seasons. As for TSS, it is clear from Table 6 that, $T_{3}$ gave the lowest values of TSS with significant differences between $T_{3}$ and other treatments in both seasons. Whereas, $\mathrm{T}_{1}, \mathrm{~T}_{2}$ and control gave high values of TSS and found to be at par without significant differences among them in both seasons. Regarding acidity, control treatment gave the lowest values of acidity compared to other treatments in both seasons. the differences were insignificant in most cases in both seasons. Generally, $T_{2}$ (4 kg Natural Raw
Material Mixture/tree $+3 \mathrm{~kg} /$ tree feldspar $+50 \mathrm{~kg}$ MOM) produced fruits with better $\mathrm{TSS} \%$ and acidity values than control .

The results in Table 7 revealed that, $T_{2}$ and control treatments gave the highest values of TSS/acid ratio compared to other treatments in both seasons. The differences were insignificant in most cases in both seasons. Moreover, all tested treatments led to increase fruit value of vitamin $\mathrm{C}$ compared to control treatment in both seasons. Trees treated with $\mathrm{T}_{2}$ (4 kg Natural Raw Material Mixture/tree $+3 \mathrm{~kg} /$ tree feldspar) gave the highest vitamin $\mathrm{C}$ in fruits followed by those treated with $\mathrm{T}_{3}$ (6 kg Natural Raw Material Mixture/tree +3 $\mathrm{kg} /$ tree feldspar), respectively.

Table 6. Effect of natural raw material mixture and feldspar on TSS\% and acidity \% of Washington navel orange trees.

\begin{tabular}{lcccccccc}
\hline & \multicolumn{4}{c}{ TSS \% } & & \multicolumn{2}{c}{ Acidity \%o } \\
\cline { 2 - 8 } Treatments & 2012 Season & $\begin{array}{c}\mathbf{2 0 1 3} \\
\text { Season }\end{array}$ & Average & $\begin{array}{c}\text { \% Increasing } \\
\text { or decreasing } \\
\text { Than control }\end{array}$ & $\begin{array}{c}\mathbf{2 0 1 2} \\
\text { Season }\end{array}$ & $\begin{array}{c}\text { 2013 } \\
\text { Season }\end{array}$ & $\begin{array}{c}\text { Average } \\
\text { Ancreasing or } \\
\text { decreasing } \\
\text { than control }\end{array}$ \\
\hline Control & $11.63 \mathrm{a}$ & $12.00 \mathrm{a}$ & 11.81 & 0.00 & $0.82 \mathrm{a}$ & $0.81 \mathrm{~b}$ & 0.81 & 0.00 \\
$\mathrm{~T}_{1}$ & $12.07 \mathrm{a}$ & $11.80 \mathrm{ab}$ & 11.93 & +1.01 & $0.87 \mathrm{a}$ & $0.85 \mathrm{ab}$ & 0.86 & +6.17 \\
$\mathrm{~T}_{2}$ & $11.90 \mathrm{ab}$ & $12.00 \mathrm{a}$ & 11.95 & +1.18 & $0.83 \mathrm{a}$ & $0.96 \mathrm{a}$ & 0.89 & +9.87 \\
$\mathrm{~T}_{3}$ & $10.97 \mathrm{c}$ & $11.60 \mathrm{~b}$ & 11.28 & -4.48 & $0.84 \mathrm{a}$ & $0.94 \mathrm{ab}$ & 0.89 & +9.87 \\
$\mathrm{LSD}$ at 5\% & 0.36 & 0.35 & -- & -- & $\mathrm{NS}$ & 0.14 & -- & - \\
\hline
\end{tabular}

Table 7. Effect of natural raw material mixture and feldspar on TSS/acid ratio and vitamin $\mathrm{C}(\mathrm{mg} / 100 \mathrm{ml}$ juice) of Washington navel orange trees.

\begin{tabular}{|c|c|c|c|c|c|c|c|c|}
\hline \multirow[b]{2}{*}{ Treatments } & \multicolumn{4}{|c|}{ TSS/acid ratio } & \multicolumn{4}{|c|}{ Vitamin C (mg/100 ml juice) } \\
\hline & $\begin{array}{c}2012 \\
\text { Season }\end{array}$ & $\begin{array}{c}2013 \\
\text { Season }\end{array}$ & Average & $\begin{array}{c}\text { \%Increasing or } \\
\text { decreasing } \\
\text { than control }\end{array}$ & $\begin{array}{c}2012 \\
\text { Season }\end{array}$ & $\begin{array}{c}2013 \\
\text { Season }\end{array}$ & Average & $\begin{array}{c}\text { \% Increasing or } \\
\text { decreasing } \\
\text { than control }\end{array}$ \\
\hline Control & $14.28 \mathrm{a}$ & $14.89 \mathrm{a}$ & 14.58 & 00.00 & $47.25 \mathrm{~b}$ & $47.21 \mathrm{c}$ & 47.23 & 00.00 \\
\hline $\mathrm{T}_{1}$ & $13.84 \mathrm{a}$ & $13.90 \mathrm{ab}$ & 13.87 & -4.86 & $52.50 \mathrm{a}$ & $59.25 \mathrm{~b}$ & 55.87 & +18.29 \\
\hline $\mathrm{T}_{2}$ & $14.34 \mathrm{a}$ & $12.59 \mathrm{~b}$ & 13.46 & -7.68 & $48.30 \mathrm{ab}$ & $68.62 \mathrm{a}$ & 58.46 & +23.77 \\
\hline $\mathrm{T}_{3}$ & $13.01 \mathrm{a}$ & $12.39 \mathrm{~b}$ & 12.70 & -12.89 & $51.10 \mathrm{ab}$ & $63.75 \mathrm{~b}$ & 57.42 & +21.57 \\
\hline LSD at $5 \%$ & Ns & 1.81 & -- & -- & 4.65 & 9.17 & -- & -- \\
\hline
\end{tabular}

- $T_{1}: 50 \mathrm{~kg}$ M O M + $2 \mathrm{~kg}$ Natural Raw Material Mixture/tree + $3 \mathrm{~kg} /$ tree feldspar

- $T_{2} 50 \mathrm{~kg}$ M O M +:4 kg Natural Raw Material Mixture/tree $+3 \mathrm{~kg} /$ tree feldspar

- $T_{3}: 50 \mathrm{~kg}$ M O M + $6 \mathrm{~kg}$ Natural Raw Material Mixture $/$ tree $+3 \mathrm{~kg} /$ tree feldspar

- Control: Farmer program fertilization

NS = not significant

Generally, it is obvious from Tables 5, 6 and 7 that, fertilization with natural raw material mixture and natural raw potassium (feldspar) are able to consistently improve fruit quality in terms of fruit weight, fruit size, 
juice size, TSS, acidity, TSS/acid ratio and vitamin C of Washington navel orange trees compared to control. In this respect, $\mathrm{T}_{2}$ (4 kg Natural Raw Material Mixture/tree $+3 \mathrm{~kg} /$ tree feldspar) and $\mathrm{T}_{3}(6 \mathrm{~kg}$ Natural Raw Material Mixture/tree $+3 \mathrm{~kg} /$ tree feldspar) produced the best fruit quality without significant differences between them. These results agree with those obtained by Abdel Rahman et al. (2009). Also, El- Wakeel et al. (2013) indicated that the best values of fruit weight, fruit volume, TSS and TSS/acid ratio of Navel orange fruits were obtained by the highest levels from potassium ( 600 $\left.\mathrm{g} \mathrm{K}_{2} \mathrm{O}\right)$ as $\mathrm{K}$ - feldspar + silicate bacteria treatments. Similarly, Baiea et al. (2015) revealed that the highest values of total soluble solids and TSS/acid ratio of banana cv. Grande Naine were scored by $8 \mathrm{Kg}$ feldspar $+10 \mathrm{ml}$ Potassin as compared to control.

Fruit quality and weight loss during shelf life period: Data in Table 8 show the effect of soil application of natural raw material mixture and natural raw potassium (feldspar) on fruit loss and chemical fruit quality of Washington navel orange fruits stored at room temperature $\left(21 \pm 1{ }^{\circ} \mathrm{C}\right)$ with humidity $(60 \pm 5 \%)$. As for fruit weight loss, data in Table 8 showed that weight loss percentage was increased by increasing storage period. The highest percentage weight loss was observed in control treatment followed by $\mathrm{T}_{1}(2 \mathrm{~kg}$ Natural Raw Material Mixture/tree $+3 \mathrm{~kg} /$ tree feldspar+50kg MOM) and $\mathrm{T}_{2}$ (4kg Natural Raw Material Mixture/tree $+3 \mathrm{~kg} /$ tree feldspar $+50 \mathrm{~kg}$ MOM) in both seasons, respectively. On the other hand, T3(6 $\mathrm{kg}$ Natural Raw Material Mixture/tree $+3 \mathrm{~kg} /$ tree feldspar $+50 \mathrm{~kg} \mathrm{MOM}$ ) gave the lowest fruit weight loss percentage during storage period as compared to the other treatments. The differences between fertilization treatments and control were significant in both seasons, while, the differences among treatments were insignificant in most cases. Weight loss of citrus fruits is related to fruit moisture loss; it is also an important factor of fruit quality. Moisture loss during storage shows a shriveled fruit of citrus and dry appearance, and it increased as increasing storage time and temperature (Nunes, 2008).

Table 8. Effect of natural raw material mixture and feldspar on weight loss \% and chemical fruit quality during storage at room temperature $\left(21 \pm 1^{\circ} \mathrm{C}\right)$ with humidity $(60 \pm 5 \%)$ of Washington navel orange trees.

\begin{tabular}{|c|c|c|c|c|c|c|c|c|c|c|c|c|}
\hline \multirow{3}{*}{ Treatments } & \multicolumn{12}{|c|}{ Weight loss (\%) } \\
\hline & \multicolumn{6}{|c|}{ Season 1} & \multicolumn{6}{|c|}{ Season 2} \\
\hline & $\mathbf{0}$ & $7 d$ & 14d & 21d & 28d & 35d & $\mathbf{0}$ & $7 d$ & 14d & 21d & 28d & 35d \\
\hline Control & 00.0 & 3.15 & 6.18 & 9.32 & 12.65 & 14.36 & 00.0 & 3.36 & 5.99 & 8.20 & 11.15 & 13.32 \\
\hline $\mathrm{T}_{1}$ & 00.0 & 2.37 & 4.53 & 7.45 & 10.07 & 11.70 & 00.0 & 3.08 & 5.80 & 7.92 & 10.76 & 12.69 \\
\hline & 00.0 & 2.44 & 4.52 & 7.11 & 9.56 & 11.48 & 00.0 & 3.02 & 5.23 & 7.20 & 9.55 & 11.33 \\
\hline & 00.0 & 2.09 & 4.04 & 6.38 & 9.03 & 10.43 & 00.0 & 2.94 & 5.49 & 7.44 & 10.40 & 12.50 \\
\hline LSD at $5 \%$ & 00.0 & 0.50 & 0.91 & 1.38 & 1.66 & 1.85 & 00.0 & 0.40 & 0.71 & 1.05 & 1.39 & 1.57 \\
\hline \multirow{3}{*}{ Treatments } & \multicolumn{12}{|c|}{ TSS (\%) } \\
\hline & \multicolumn{6}{|c|}{ Season 1} & \multicolumn{6}{|c|}{ Season 2} \\
\hline & $\mathbf{0}$ & $7 d$ & 14d & 21d & 28d & 35d & $\mathbf{0}$ & $7 d$ & 14d & 21d & 28d & 35d \\
\hline Control & 11.63 & 12.03 & 12.13 & 12.20 & 12.93 & 13.03 & 11.27 & 11.67 & 12.00 & 12.13 & 12.13 & 12.67 \\
\hline $\mathrm{T}_{1}$ & 11.70 & 12.07 & 12.60 & 13.07 & 13.07 & 13.33 & 11.40 & 11.47 & 11.67 & 11.80 & 12.27 & 12.4 \\
\hline $\mathrm{T}_{2}$ & 11.70 & 11.90 & 12.27 & 12.70 & 12.53 & 12.73 & 11.80 & 12.00 & 12.20 & 12.27 & 12.33 & 12.67 \\
\hline $\mathrm{T}_{3}$ & 10.97 & 11.13 & 11.80 & 12.13 & 12.47 & 13.00 & 11.00 & 11.43 & 11.47 & 11.60 & 12.07 & 12.27 \\
\hline LSD at $5 \%$ & 0.31 & 0.35 & 0.22 & 0.32 & 0.17 & 0.32 & 0.32 & 0.17 & 0.17 & 0.49 & 0.27 & 0.25 \\
\hline \multirow{3}{*}{ Treatments } & \multicolumn{12}{|c|}{ Acidity (\%) } \\
\hline & \multicolumn{6}{|c|}{ Season 1} & \multicolumn{6}{|c|}{ Season 2} \\
\hline & $\mathbf{0}$ & $7 d$ & 14d & 21d & 28d & 35d & $\mathbf{0}$ & $7 d$ & 14d & 21d & 28d & 35d \\
\hline Control & 0.82 & 0.82 & 0.85 & 0.83 & 0.83 & 0.81 & 0.81 & 0.82 & 0.84 & 0.82 & 0.79 & 0.78 \\
\hline $\mathrm{T}_{1}$ & 0.87 & 0.92 & 0.96 & 0.92 & 0.85 & 0.82 & 0.85 & 0.92 & 0.87 & 0.87 & 0.86 & 0.84 \\
\hline $\mathrm{T}_{2}$ & 0.83 & 0.91 & 0.95 & 0.87 & 0.85 & 0.82 & 0.86 & 0.91 & 0.94 & 0.90 & 0.84 & 0.82 \\
\hline & 0.84 & 0.91 & 0.89 & 0.82 & 0.81 & 0.80 & 0.86 & 0.91 & 0.86 & 0.86 & 0.82 & 0.80 \\
\hline LSD at $5 \%$ & 0.03 & 0.03 & 0.02 & 0.03 & 0.81 & 0.01 & 0.01 & 0.03 & 0.03 & 0.03 & 0.03 & 0.02 \\
\hline \multirow{3}{*}{ Treatments } & \multicolumn{12}{|c|}{ TSS/acid ratio } \\
\hline & \multicolumn{6}{|c|}{ Season 1} & \multicolumn{6}{|c|}{ Season 2} \\
\hline & $\mathbf{0}$ & $7 d$ & 14d & 21d & 28d & 35d & $\mathbf{0}$ & $7 d$ & 14d & 21d & 28d & 35d \\
\hline Control & 14.20 & 14.67 & 14.28 & 14.70 & 15.58 & 16.10 & 12.91 & 13.12 & 14.29 & 14.80 & 15.36 & 16.17 \\
\hline $\mathrm{T}_{1}$ & 13.41 & 13.12 & 13.13 & 14.21 & 15.38 & 16.27 & 13.42 & 11.95 & 13.36 & 13.57 & 14.21 & 14.78 \\
\hline $\mathrm{T}_{2}$ & 14.06 & 13.03 & 12.91 & 14.56 & 14.75 & 15.53 & 13.72 & 12.50 & 12.94 & 13.58 & 14.68 & 15.46 \\
\hline & 13.06 & 12.19 & 13.28 & 14.74 & 15.39 & 16.18 & 12.79 & 12.08 & 13.33 & 13.79 & 14.66 & 15.27 \\
\hline \multirow[t]{2}{*}{ LSD at $5 \%$} & 0.85 & 0.87 & 0.22 & 0.80 & .052 & 0.71 & 0.52 & 0.71 & 0.56 & 0.97 & 0.43 & 0.74 \\
\hline & \multicolumn{12}{|c|}{ Vitamin C ( mg/100 ml juice) } \\
\hline \multirow[t]{2}{*}{ Treatments } & \multicolumn{6}{|c|}{ Season 1} & \multicolumn{6}{|c|}{ Season 2} \\
\hline & $\mathbf{0}$ & $7 d$ & 14d & 21d & 28d & 35d & $\mathbf{0}$ & 7d & 14d & 21d & 28d & 35d \\
\hline Control & 47.25 & 46.45 & 45.71 & 34.45 & 30.33 & 25.47 & 47.21 & 46.24 & 44.04 & 32.16 & 29.14 & 25.71 \\
\hline $\mathrm{T}_{1}$ & 48.56 & 47.73 & 45.90 & 34.45 & 29.67 & 25.31 & 47.67 & 47.05 & 44.34 & 33.84 & 30.08 & 27.89 \\
\hline $\mathrm{T}_{2}$ & 48.30 & 47.52 & 45.54 & 37.30 & 29.42 & 27.11 & 47.89 & 47.21 & 44.53 & 34.32 & 31.40 & 28.48 \\
\hline & 49.87 & 48.16 & 46.81 & 37.85 & 29.01 & 27.33 & 49.24 & 48.44 & 45.64 & 35.28 & 32.28 & 29.27 \\
\hline LSD at $5 \%$ & 1.04 & 0.65 & 0.26 & 0.51 & 0.90 & 0.36 & 0.62 & 0.64 & 0.58 & 0.38 & 0.24 & 0.48 \\
\hline
\end{tabular}

- T $_{1:}$ 50kg M O M + 2 kg Natural Raw Material Mixture/tree + 3 kg/tree feldspar

- $T_{2:} 50 \mathrm{~kg}$ M O M + $4 \mathrm{~kg}$ Natural Raw Material Mixture/tree $+3 \mathrm{~kg} /$ tree feldspar

- $T_{3}: 50 \mathrm{~kg}$ M O M 6 kg Natural Raw Material Mixture /tree $+3 \mathrm{~kg} /$ tree feldspar

- Control: Farmer program fertilization

- d: day 
The results in Table 8 indicate that total soluble solid (TSS) in Washington navel orange fruits increases gradually as storage time progressed. The treatments of $T_{1}$ and $T_{2}$ gave the highest values of total soluble solid (TSS) without significant differences between them in most cases as compared to control and other treatments in both seasons. Thus, using natural raw material mixture and natural raw potassium (feldspar) as fertilizers maintain high level of total soluble solids (TSS) during storage period. The increase in total soluble solids in fruits maybe related to the hydrolytic activities in starch, the increased activity of enzymes responsible for the hydrolysis of starch to soluble sugars, and the conversion of starch to sugar, which indicates that the fruits are at the ripening process (Ghosh and Sen, 1984).

Regarding fruit acidity, it increased in the first and second week with all treatments when compared with control and the differences were significant among them in most cases, and then began to decline from the third week until the fifth week. Control fruit was the lowest in the percentage of acid followed by treatments $T_{3}, T_{2}$ and $T_{1}$ respectively, with significant differences among them in most cases.

Regarding TSS/ Acidity, data in Table 8 indicate that, the values were approximated from the harvest time until the second week for all treatments. The values of the control were the highest with significant differences between them and the other treatments. The values increased in the third, fourth and fifth weeks respectively compared to the values at the harvest time with all treatments. TSS/Acidity values started to increase with all treatments without insignificant differences among them and control in most cases in the first season, this is due to the decrease in acidity and increase the value of TSS in fruit as a result of the loss water content as a result of breathing and evaporation.

As for $\mathrm{VC}$, data in table 8 show that, the values of $\mathrm{VC}$ increased from the harvest time until the fifth week with all treatments and the highest values were found with the third treatment and the differences were significant when compared to the control and the other treatments .

Generally, data in table 8 clear that, the values of TSS, TSS / Acidity and loss in fruit weight were increased from the beginning of shelf life until the fifth week, while the values of $\mathrm{VC}$ and percentage of acid were decreased from one week to the next. The use of a natural mineral mixture of $4 \mathrm{~kg}$ with $3 \mathrm{~kg}$ potassium (Feldspar) increased the values of TSS and TSS / acidity compared to control, except for $\mathrm{VC}$ values and the loss of fruit weight. The treatment of chemical fertilizer (control) led to an increase in the percentage of loss in weight of fruit during the storage period.

\section{REFERENCES}

Abdel Rahman, M.; A. El-Metwally and Y. Ibrahim (2009). Effect of natural elements compound applications on citrus trees and seedlings production. Egypt J. of Appl. Sci., 24(10A):293 -307 .
Abdel-Hak R.S.; S. El-Shazly; A. El-Gazzar; E.A. Shaaban and M.S. El-Shamma (2012). Response of Valencia orange trees to rock-feldspar applications in reclaimed soils. J. Appl. Sci. Res., 8(7): 3160-3165.

Association of official Agriculture chemists (1990). Official and Tentative Methods of Analysis, (the AOAC 13th ed. Washington, D C, USA).

Baiea, M.H.M.; S.F. EL-Gioushy and T.F. El-Sharony (2015). Effect of feldspar and bio- fertilization on growth, productivity and fruit quality of Banana cv. Grande Naine. Int. J. Environ., 4(4): 210-218.

Barakat, M.R.; T.A. Yehia and B.M. Sayed (2012). Response of Newhall naval orange to bio-organic fertilization under newly reclaimed area conditions I: Vegetative growth and nutritional status. J. Hort. Sci. \& Ornamen. Plants, 4(1): 1825.

Brown, J.D. and O. Lillelland (1974). Rapid determination of potassium and sodium in plant material and soil extracts by flame photometer. Proc. Soc. Hort. Sci., 48: 341-346.

Chapman, H.D. and P.F. Pratt (1961). Methods of Analysis for Soils, Plant and Waters. Univ. of California, USA, pp. 169-170.

El-Boray, M.S.; Mostafa, M.F and Hamed, A.(2007).Effect of some biostimulants on yield and berry quality of grapevines. J. Agric .Sci. Mansoura Univ., 32(6): 5001-5007.

El-Boray, M.S.; Mostafa, M.F, Salem, S.E. and ElSawah, O. (2015).Improving yield and fruit quality of Washington navel orange using foliar application of some natural biostimulants. J. Plant Production Mansoura Univ ., 6(9):1297 1311.

El-Iraqy, M.A.E. (2014). Effect of bio fertilizers and natural minerals on productivity and fruit quality of olive trees cv. "Picual". International Journal of Plant \& Soil Science, 3(11): 1387-1397.

El-Wakeel H.F.; N. Mansour; M. Mubarak and E.A. Hassan (2013). The response of bearing Navel orange trees to some sources and rates of potassium fertilizers and silicate bacteria. J. Appl. Sci. Res., 9(11): 5780-5793.

Eman, S.A.; W.M. Abd El-Messeih and G.B. Mikhael (2010). Using of natural raw material mixture and magnetite raw (magnetic iron) as substitute for chemical fertilizers in feeding Le Conte pear trees planted in calcareous soil. Alex. Sci. Exch. J., 31(1):51-62.

Embleton, T.W.; W.W. Jones; C. Pallares and R.C. Platt (1978). Effects of fertilization of citrus on fruit quality and ground water nitrate pollution potential. Proc. Int. Soc. Citriculture 1:280.

Ennab, H.A. (2016). Effect of organic manures, biofertilizers and NPK on vegetative growth, yield, fruit quality and soil fertility of Eureka lemon trees (Citrus Limon (L.) Burm). Soil Sci. and Agric. Eng. Mansoura Univ.,7(10):767-774 
Ghosh, S.K. and S.K. Sen (1984). Extension of storage life of sweet orange (Citrus sinensis Osbeck) cv. Mosambi. South Indian Hort., 32: 16 - 22.

Hegazi, A.H.; N.R. Samra; E.A. Hassan; and A.M. Yasmin (2014). Effect of compost as organic fertilizer, rocks and some different biofertilizers on yield and quality of flame seedless grapevines. J. Plant Production, Mansoura Univ., 5 (10): 1625 - 1636.

Jackson, M.L. (1967). Soil Chemical and Analysis. Prentice Hall of India, New Delhi, p. 498.

Jacobs, M. B. (1951). The Chemical Analysis of Foods and Food Products: 724 - 732. D. Van. Nostrand., Inc. Now York, London.

Koo, R. C. J.; C. A. Anderson; I. Stewart; D. P. H. Tucker; D. V. Calvert, and H. K. Wutscher (1984). Recommended fertilizers and nutritional sprays for citrus. Fla. Coop. Extension Serv. Bulletin. 536D.

Mohamed, N.M. (2008). Reducing agrochemical residues in grapes by using different sources from bio and organic fertilizers. Ph.D. Thesis, Institute of Environ. Stud., and Res., Ain Shams Univ.

Mostafa, R.A.A. and M.M.A. Abdel-Rahman (2015). Effects of natural and bio-fertilization as a partial substitute for mineral fertilization on vegetative growth and fruiting of Balady mandarin trees. Assiut J. Agric. Sci., 46(1): 34 - 47.

Murphy, J. and Riley, J.R. (1962). A modified single solution method for the determination of phosphorus in natural water. Anal. Chem., Acta, 27: 31-38.

Nunes, M.C.N. (2008). Color Atlas of Postharvest Quality of Fruits and Vegetables. 463p. In M.C.N. Nunes (ed.) Wiley-Blackwell Publishing, Ames, Iowa, USA.
Page, A.L.; Miller H. and Keeney, D.R. (1982). Methods of Soil analysis. part 2: Chemical and Microbiological Properties. 2nd Edition, Agronomy Monograph, No. 9, ASA, CSSA, and SSSA, Madison.

Pregl, F. (1945).Quantitative Organic Microanalysis, 4th ed J.A. Churchill, Ltd, London.

Roy, R.N.; A. Finck; G.J. Blair and H.I.S. Tandon (2006). Plant nutrition for food security: A guide for integrated nutrient management. Chapter 7: Guidelines for the management of plant nutrients and their sources. Rome: FAO, Pp: 193 - 232. (FAO Fertilizer and Plant Nutrition Bulletin, 16). ISBN $92-$ 5-105490-8.

Shaaban, E.A.; M.S. El-Shamma; S. El Shazly; A. ElGazzar and R.E. Abdel-Hak (2012). Efficiency of rock-feldspar combined with silicate dissolving bacteria on yield and fruit quality of Valencia orange fruits in reclaimed soils. J. Appl. Sci. Res., 8(8):4504 $-4510$.

Shaheen, M.A.; S.M. Abd El Wahab; F.M. El-Morsy and A.S.S. Ahmed (2013). Effect of organic and biofertilizers as a partial substitute for NPK mineral fertilizer on vegetative growth, leaf mineral content, yield and fruit quality of Superior grapevine. J. Hort. Sci. \& Ornamen. Plants, 5(3): 151-159.

Snedecor, G.W. and W.G. Cochran (1990).Statistical Methods. 7th Ed. Iowa State Univ. Press. Ames., Iowa, USA, p. 593.

Srivastava, A.K. (2012). Integrated nutrient management. In: Advances in Citrus Nutrition. A.K. Srivastava (Ed.)Springer-Verlag, The Netherlands,pp. 369-389.

Zayan, M.A.; R.A. Sayed; A.R. El-Sherif and H.M. ElZawily (2016). Irrigation and fertilization programs for Washington navel orange trees in sandy soil under desert climatic conditions. 1. Effect on soil properties, vegetative growth and yield. J. Agric. Res., Kafr El-Sheikh Univ. A. Plant Production, 42(2):244-267.

\footnotetext{
استخدام مخلوط المعادن الطبيعيه و خام البوتاسيوم الطبيعى كبديل للأسمده الكيماويه فى تغذيه اشجار البرتقال ابو

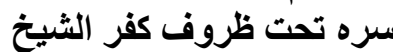

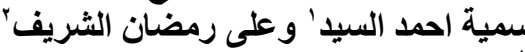

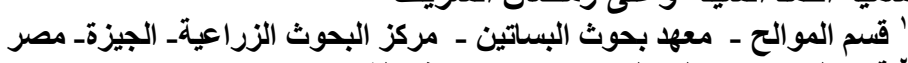

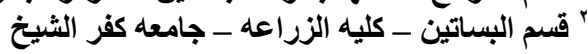

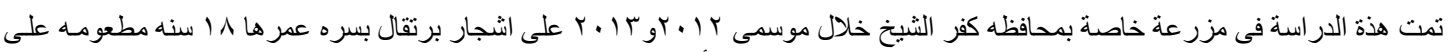

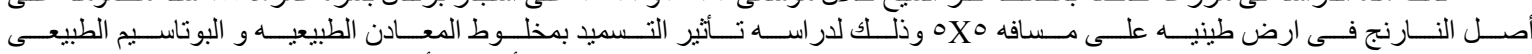

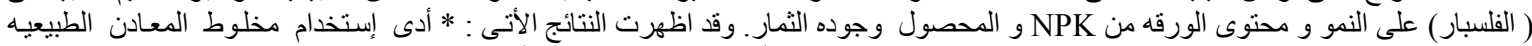

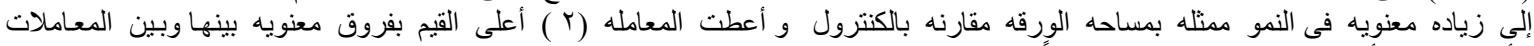

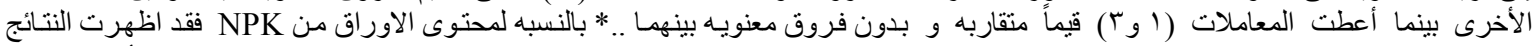

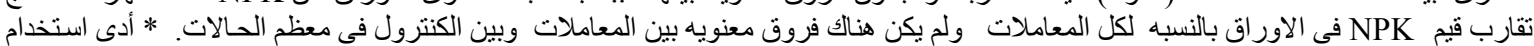

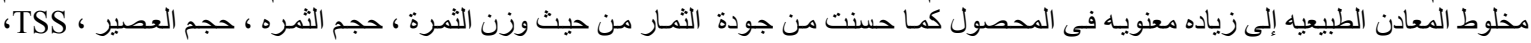

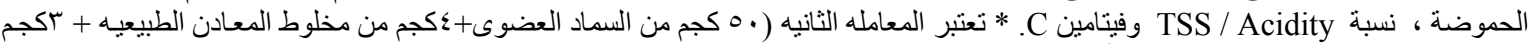

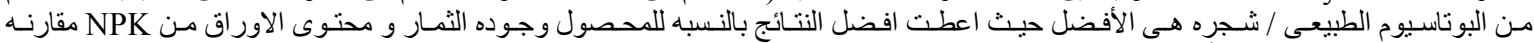

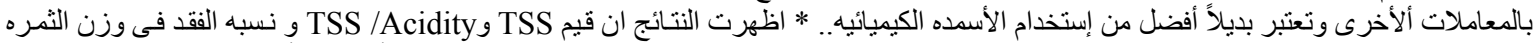

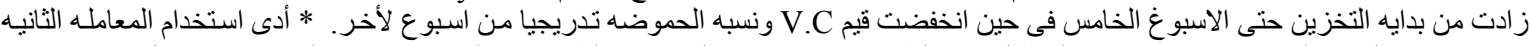

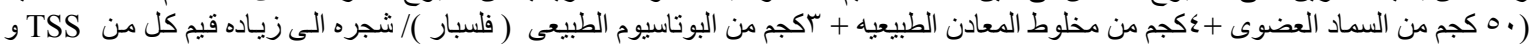

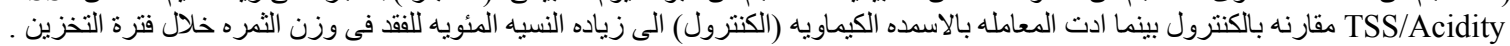

